\title{
INTRAREGIONAL VARIABILITY AND PLACE-SPECIFIC ELECTORAL BEHAVIOR IN UKRAINE
}

\author{
Mykola DOBYSH \\ Taras Shevchenko National University of Kyiv, Ukraine \\ mpetrovych@gmail.com
}

\begin{abstract}
The paper criticizes electoral geography studies of Ukraine, where the territory of the country is artificially divided into a number of regions following administrative divisions. The study reveals intraregional variability in the territorial patterns of voting behavior in Ukraine in 2002-2014. Zakarpattya, Chernivtsi, Sumy, Chernigiv, and Zhytomyr oblasts have the highest intraregional variance of electoral preferences for conventional "national-democratic" and "Communists and proRussian" political parties. All oblasts of Ukraine have internal variations of voting behavior. It was studied based on electoral results data for rayons and cities with special administrative status $(n=675)$. Scatterplot with a time scale, filters for oblasts and rayons/cities, and the opportunity to draw electoral preferences trajectories from 2002 to 2014 parliamentary elections was used as a research instrument. The study also reveals region-specific voting patterns of cities and territorial outliers, which are bounded by administrative borders places with unique voting behavior. The paper accentuates place-specific and region-ascontext understanding of electoral behavior as an essential conceptual framework for the further electoral geography studies of Ukraine.
\end{abstract}

Key words: electoral geography of Ukraine, intraregional variability of voting patterns, place-as-context, region-as-context, regional differences in Ukraine.

DOI: https://doi.org/10.17721/2413-7154/2018.79.4-17

UDC: $911.3: 324$

Received: October 10, 2018.

Accepted: November 13, 2018.

\section{ВНУТРІШНЬОРЕГІОНАЛЬНА ВАРІАТИВНІСТЬ ТА МІСЦЕВА СПЕЦИФІКА ЕЛЕКТОРАЛЬНОЇ ПОВЕДІНКИ В УКРАЇНІ}

\author{
Микола дОБиш \\ Київський начіональний університет імені Тараса Шевченка, Україна \\ mpetrovych@gmail.com
}

\begin{abstract}
Анотація: В статті критикуються електорально-географічні дослідження України, які штучно ділять територію країни на регіони, слідуючи адміністративним кордонам. Проведене дослідження розкриває внутрішньорегіональні відмінності територіальних закономірностей голосування в Україні в 2002-2014 роках. Закарпатська, Чернівецька, Сумська, Чернігівська та Житомирська області мають найбільше значення внутрішньорегіональної варіації в електоральних вподобаннях умовних «національно-демократичних» та «комуністичних та проросійських» політичних партій. Всі області України мають внутрішні відмінності електоральної поведінки. Дослідження проводилося на

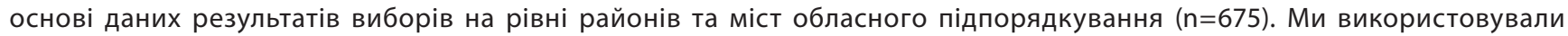
скаттерплот з часовою шкалою, фільтрами за областями та районами/містами, а також можливістю промальовувати траєкторію електоральних вподобань від парламентських виборів 2002 року до парламентських виборів 2014 року як дослідницький інструмент. Дослідження також розкриває регіональні особливості закономірностей голосування міст та територіальні статистично відмежовані результати (outliers), які являють собою обмежені адміністративними кордонами місцями з унікальною електоральною поведінкою. Стаття наголошує на розумінні електоральної поведінки як визначеної специфікою географічних місць та регіоном-як-контекстом як важливих концептуальних рамок для подальших досліджень електоральної географії України. Місця і регіони в електоральній географії $\epsilon$ часовопросторовими конфігураціями, що мають транзиторний тимчасовий характер. Кореляційний аналіз композиційних змінних не здатний повною мірою розкрити причини формування різних просторових структур поведінки голосування у різних часових контекстах і, водночас, існування стійких закономірностей електоральних переваг в межах окремих територій. Будь-яка регіоналізація, здійснена з метою дослідження, $\epsilon$ довільною, тому науковцям слід насамперед звертати особливу увагу на те, як територія країни структурована виборчими результатами на найнижчому можливому рівні та у динаміці задля виявлення регіональних та локальних моделей голосування. Регіони та місця не $\epsilon$ однорідними, і можуть по-різному сприйматися різними соціальними групами, створюючи, проте, унікальні умови для електоральних симпатій.
\end{abstract}

Ключові слова: електоральна географія України, внутрішньорегіональні відмінності в голосуванні, місце-якконтекст, регіон-як-контекст, регіональні відмінності в Україні. 


\section{Introduction}

Understanding of region as an essential primordial formation or using of region concept for artificially grouped administrative units cannot grasp spatial heterogeneity of electoral preferences in Ukraine. The semantic flexibility of the concept of region also causes conflicts over its use in geographical studies (Paasi, 1991). Cartographic anxiety, when the territory of the country is pushed to be represented as a cartographicfriendly bounded whole (Painter, 2008), also limits understanding of regional dimension of voting behavior in Ukraine. Most of the research on regional differences in electoral preferences in the country is based on a binary opposition between East and West (S. Birch \& Wilson, 1999; Brooks, Nieuwbeerta, \& Manza, 2006; R. S. Clem \& Craumer, 2008; Kubicek, 1999; Liber, 1998; Riabchuk, 2015), artificial division of Ukraine into decided by scholar number of regions (Barrington, 1997; Barrington \& Herron, 2004; R. Clem \& Craumer, 2005; R. S. Clem \& Craumer, 2008; Colton, 2011; Holdar, 1995; Katchanovski, 2014), use of administrative borders at oblast level for the shape of historical regions (Sarah Birch, 2000; Haydukiewicz, 2011; Katchanovski, 2006), use of administrative units as a key for statistical analysis and interpretation of electoral results in Ukraine (Brooks et al., 2006; Hinich, Khmelko, \& Ordeshook, 1999; Khmelko, Semenova, Teleshun, \& Titarenko, 2011; Shevel, 2015). Consequently, the concept of region in electoral studies of Ukraine should be reviewed considering existing geographical theory of region-ascontext, blurred and fluid territorial shapes of regions, and correspondence between region and place.

Chorological approach to regional studies is still essential for scientific constructions of regional variables. However, analysis of electoral results in Ukraine is often based not on the preliminary study of the spatial differences of settlement process, legacies of previous political borders, economic development path, and cultural peculiarities of the territories to draw lines between places that have specific criteria of distinction, but on construction of simplified and artificial macroregions that are composed of administrative oblasts. Administrative units became an essential part of structuration of territorial phenomena in electoral studies of Ukraine. Partially it is due to an obsession with quantitative analysis and available statistics. However, Paasi (1991) accentuates that regions could not be narrowed to administrative borders and Agnew (1996) in his place theory also underlines limits of analysis based on categories that are accumulated for administrative units. Therefore, available data for quantitative analysis creates a trap for geographical studies and understanding of territorial shapes of electoral results.

The paper aims to clarify the use of region and place concepts in the interpretation of electoral preferences in Ukraine and reveals intraregional variability, temporal and persistent territorial shapes of voting behavior in the country. The study is based on data from Central Electoral Office on electoral returns at the level of rayons

(C) Mykola Dobysh and cities with spatial administrative status $(\mathrm{n}=675)$ for parliamentary elections of 2002, 2006, 2007, 2012, and 2014. Parties in Ukraine where conventionally divided into "national-democratic" and "communist and proRussian" groups following polarization and the main fault lines of Ukrainian politics in 2002-2014. Such artificial divide was constructed for the comparative study of parliamentary elections 2002-2014 because some parties were disappearing, and some emerged in the Ukrainian political landscape during the studied period. Small parties who received less than $1 \%$ of the popular vote were excluded from the sample with the exception for strongly pro-Russian in their rhetoric parties like Russkiy Block, ZUBR, SOUZ. Parties who built their rhetoric on the "third side" position (for example, Socialist Party and Lytvyn's Block) were not included in these two rivalry groups. Using Microsoft Power BI as an instrument, scatterplot with a timescale, filters for oblasts and rayons, and the opportunity to draw electoral preferences trajectories of rayons and cities was created. It was used as an analytical tool to reveal intraregional variability, outliers, and temporal and persistent patterns of voting behavior. The paper is organized into three sections. The first examines opportunities of the existing theories of region and regional identity to be used in electoral geography. The second reveals intraregional variability within oblasts as the most common units of analysis in electoral geography studies of Ukraine. The third analyzes regions as context for the interpretation of electoral results and rayons and cities that are outliers form their regional patterns as specific places of electoral behavior.

\section{Understanding place and region in electoral geography studies}

Murphy (2008, p. 9) argues that metageographical conceptions are essential in organizing understandings of the world. Place and region are such concepts that are the most frequently used in the interpretation of electoral returns. Agnew (1999, p. 97) assumes that regions reflect differences in the world as well as ideas about differences. Consequently, interpretation of electoral preferences using regional variable reveals how ideas about differences in Ukraine are framed. First, we have a scalar fix of the West-East divide, which also includes orientalization of Eastern Ukraine (von Löwis, 2015). Second, an artificial construction of regions and use of administrative borders of oblasts shows domination of quantitative approach without additional in-depth studies or qualitative research as well as the examination of intraregional variability. Third, appeal to historical legacies, culture, and identity is often limited to the territorial shape of historical or identity regions using contemporary administrative boundaries. However, some studies got rid of that trap. Osipian (2012) study of historical experiences reveals intraregional variations in South-Eastern Ukraine. It corresponds with SchmittEgner (2002) understanding of region as a historical landscape with collective historical memories. Peisakhin (2013b, 2013a) also shows differences in political views along the historical border of Austrian and Russian 
empires, which divides historical regions of Galicia, Bukovina, Volhynia, and Podolia. Gentile (2015) reveals local peculiarities of geopolitical orientations among citizens of Lugansk and Stakhanov (renamed to Kadiivka) criticizing homogenization of regions in Ukraine.

O'Loughlin (2001) and Gentile (2015) are critical of typical regional dummies in studies of political views in Ukraine. However, region is not about level of analysis and could not be reduced to the scale of research (Paasi, 1991). Paasi historical and institutional approach to the understanding of region and regionalism may have value for the understanding of electoral behavior in Ukraine, but the inertia of administrative structures and superiority of the administrative elites over traditional regionalists in Ukraine (Stölting et al., 2005) put some limitations on it. Establishment of the region, despite possible blurred and fluid borders, in Paasi (1986; 1991; 2002) terms should have four fundamental components: (1) territorial shape, (2) symbolic shape, (3) number of institutions, (4) established identity. Despite the absence of studies which use Paasi's theory for the analysis of spatial differences in political beliefs in Ukraine, we may suggest that mobilization of Donbas region by Party of Regions in 2002-2012 was based on all four components of region in Paasi's model. However, we should admit that electoral maps on polling station level reveal that territorial shape of electoral Donbas region was not limited to the historical industrial region of Donbas but was also spread to less urbanized and industrialized north of Donetsk and Lugansk oblasts showing the power of administrative elites in Ukraine. It supposes that regional financial-oligarchic clans in Ukraine are also not only connected to specific industrial places where wealth is created but project their influence on the whole administrative units. Therefore, Paasi (1991) model use in electoral studies can reveal how territorial and symbolical shapes of regions are created by parties and in the case of Ukraine by administrative elites and oligarchs. Although Paasi (2013) was studying mobilization of regional identity in regional planning, we assume that political parties also might mobilize regional identities to reach their political goals, which is illustrated by the case of the Party of Regions in Donbas.

The concept of regional identity also has semantic ambiguity. First, we should distinguish regional consciousness from identity of the region (Paasi, 1986; 2003). Most of the works on regions in Ukraine are rather about identity of the region, which could be (1) scientific classification to demonstrate territoriality of some phenomena, (2) images of the regions by outsiders and insiders, which are not revealing the existence of regional consciousness as such (Paasi, 1986). In this case, regional geographers may be involved in power-knowledge relations when "creating bounded 'orders' on the earth" (Paasi, 2003). However, not only geographers but also parties and their political consultants as practitioners of electoral campaigns may create those "bounded orders" of how population should perceive the symbolical shape of the country's territory. Consequently, mediation between agency and structure can be revealed through the abstract concept of region. Territorial shapes that could be found on electoral maps are hints for the studies of agency that resulted in such territorial structure. In Paasi (1991) terms such territorial structures are reproduced by (1) formal identity-framing vehicles - education, law, and local politics, (2) local organizations, clubs, media, and societies, (3) informal conventions. Such reproduction may be also essential for political parties to maintain their level of support. Rodgers (2006) study of the politics of school textbooks in Kharkiv, Sumy, and Lugansk oblasts in Ukraine reveals how education can frame political views. While Sumy is the most aligned with the Center narrative of the history of Ukraine, Kharkiv and Lugansk narratives about territory and history of their regions conflict with "official" state narration.

Therefore, region as a medium of social interactions (Gilbert, 1988) is of higher value for electoral studies than artificially constructed and composed with existing administrative borders regions. At the same time, we can understand regions as a local response to political processes and agenda on the national level. In this case, region is a context where interaction happens. It is a setting where messages of political parties are filtrated and interpreted. Following Sayer (1989) logic regions are "causal contexts", which frame how factors of electoral behavior may be understood. On the other hand, Agnew (1996) proposes a place-as-context concept for the interpretation of territorial patterns of electoral behavior. In his theory of place, it has no limitation to specific geographical scale or level and is used to bind together different geographical scales and opposes nongeographical explanations of spatial differences in voting. Therefore, in some cases region also could be understood as a place in electoral geography. At the same time, Paasi (1991, p. 249) assumes that region instead of place has longer historical duration and higher scale history under which individuals are socialized. He also assumes that in everyday life regions may transform themselves to constitute a part of one's place and difference between region and place is about their relationship to one's daily life (1986, p. 112).

Therefore, in Paasi logic places in electoral geography might be understood as contexts of everyday practices penetrated by electoral campaigns, while regions are framing them as a context of socialization, which may also influence political beliefs. At the same time, parties may mobilize regional identities and be institutions of regionalization creating a context for socialization. Agnew (1996) suggests somewhat different logic. For him, micro-geography of everyday life is only part of the understanding of place concept for electoral studies. Agnew (1996; 2002) suggests that electoral behavior is influenced by place-specific social division of labor, access to communication technology and nature of it, social divisions in the place that are promulgated by political movements, the way place is embedded into state, political rhetoric in the place about region, other places, nation, class, gender, and ethnicity. At the same time, place should not be understood as a homogenous whole, but as full of conflicts and differences (Agnew, 1996) framed by mentioned above factors. Despite semantic variety 
and theoretical differences in understanding region and place concepts, we can assumes that concept of region in electoral geography of Ukraine may be used not only for artificial divide of the territory following administrative lines, but also as (1) institutionalized by parties bounded whole with mobilization of regional identity for party identification and alignment, (2) historical context into which inhabitants are socialized and which is a "causal context" for the interpretation of electoral behavior. Following Agnew's logic place in electoral geography is not only about micro-geography of everyday life, but also about place-specific political performance and local response to that performance and is not limited to specific geographical scale or level.

\section{Intraregional variability of electoral preferences in Ukraine}

The most common approach to studies of regional differences in electoral behavior in Ukraine is an artificial division of the country into regions following administrative borders of oblast level or using oblasts as regions. There are two main problems with such approach: (1) electoral preferences do not obviously follow administrative borders, (2) it ignores intraregional variability and simplifies electoral behavior to the effect of population composition on electoral outcomes. Therefore, we examined intraregional voting variability at the oblast level using electoral data for administrative rayons and cities with special status. The results (Table 1) show that while some oblasts have a high level of the consolidation of voting patterns, there is a significant variance of electoral outcomes at analyzed parliamentary elections in Sumy, Chernihiv, Chernivtsi, Zhytomyr, and Zakarpattya oblasts (Figure 1, Annexes A, B, C). Contrarily, Donetsk and Lugansk oblasts on the one territorial pole and Lviv, Ternopil and Ivano-Frankivsk oblasts on the other have the highest level of intraregional consolidation of voting behavior. Dynamics of voting patterns reveals that while Zakarpattya and Zhytomyr oblasts shifted to "national-democratic" vote in 2014, Chernivtsi, Sumy, and Chernihiv oblasts remained significantly divided. However, not only mentioned above, oblasts with highest intraregional deviations, have essential intraregional differences. Poltava, Kyiv, Dnipropetrovsk, Volyn, and Rivne oblasts have outliers with dramatically different voting patterns. Kharkiv, Odesa, Kherson, Kirovograd, Vinnytsya, and Khmelnytskyi have clusters of rayons and cities with substantial variation of support for "nationaldemocratic" or "pro-Russian and communist" parties.

Intraregional variability of electoral preferences has different nature that depends on regional contexts

Intraregional variance of voting in parliamentary elections 2002, 2012, and 2014

Table 1 (calculated as average deviance from the regional mean for each group of parties at rayon level)

\begin{tabular}{|c|c|c|c|c|c|c|}
\hline Region & $\begin{array}{c}\text { National- } \\
\text { De mocratic } 2002\end{array}$ & $\begin{array}{l}\text { Corrmuristipro- } \\
\text { Russian } 2002\end{array}$ & $\begin{array}{c}\text { Natioral- } \\
\text { Democratic } 2012\end{array}$ & $\begin{array}{l}\text { Cormurist/pro- } \\
\text { Russian } 2012\end{array}$ & $\begin{array}{c}\text { National- } \\
\text { De mocratic } 2014\end{array}$ & $\begin{array}{c}\text { Corrmumistipro- } \\
\text { Russian } 2014\end{array}$ \\
\hline AR Crimea & 0.0504 & 0.0295 & 0.0395 & 0.0381 & & \\
\hline Vinurytsya & 0.0772 & 0.0473 & 0.0556 & 0.0564 & 0.0283 & 0.0106 \\
\hline Volyn & 0.0407 & 0.0344 & 0.0666 & 0.0595 & 0.0333 & 0.0131 \\
\hline Driprope trovsk & 0.0605 & 0.0575 & 0.0488 & 0.0485 & 0.0578 & 0.0593 \\
\hline Donetsk & 0.0170 & 0.0422 & 0.0263 & 0.0310 & $0.0831^{*}$ & $0.0737^{*}$ \\
\hline Zhytornyr & 0.0861 & 0.0755 & 0.0762 & 0.0760 & 0.0355 & 0.0202 \\
\hline Zakarpattya & 0.0773 & 0.0391 & 0.0938 & 0.0886 & 0.0374 & 0.0153 \\
\hline Zaporizhya & 0.0233 & 0.0437 & 0.0582 & 0.0620 & 0.0779 & 0.0676 \\
\hline Fano-Frankivsk & 0.0347 & 0.0179 & 0.0195 & 0.0160 & 0.0159 & 0.0049 \\
\hline Kyiv & 0.0619 & 0.0545 & 0.0668 & 0.0626 & 0.0204 & 0.0152 \\
\hline Kirovohrad & 0.0647 & 0.0711 & 0.0531 & 0.0536 & 0.0333 & 0.0273 \\
\hline Lugarsk & 0.0171 & 0.0522 & 0.0276 & 0.0281 & $0.06151^{*}$ & $0.0642^{*}$ \\
\hline Lwiv & 0.0357 & 0.0259 & 0.0159 & 0.0151 & 0.0080 & 0.0060 \\
\hline Mykolair & 0.0302 & 0.0628 & 0.0580 & 0.0574 & 0.0484 & 0.0462 \\
\hline Odessa & 0.0448 & 0.0904 & 0.0656 & 0.0622 & 0.0930 & 0.0829 \\
\hline Poltava & 0.0542 & 0.0666 & 0.0466 & 0.0507 & 0.0268 & 0.0233 \\
\hline Rivne & 0.0794 & 0.0585 & 0.0670 & 0.0623 & 0.0252 & 0.0098 \\
\hline Surny & 0.0861 & 0.1215 & 0.1279 & 0.1238 & 0.0986 & 0.0738 \\
\hline Te ropil & 0.0243 & 0.0124 & 0.0367 & 0.0299 & 0.0114 & 0.0067 \\
\hline Kharkiv & 0.0268 & 0.0693 & 0.0651 & 0.0674 & 0.0826 & 0.0885 \\
\hline Kherson & 0.0404 & 0.0517 & 0.0659 & 0.0660 & 0.0556 & 0.0513 \\
\hline Khure lnytskyi & 0.0619 & 0.0439 & 0.0481 & 0.0426 & 0.0258 & 0.0086 \\
\hline Cherkasy & 0.0643 & 0.0411 & 0.0487 & 0.0465 & 0.0151 & 0.0149 \\
\hline Chemivtsi & 0.1215 & 0.0667 & 0.1110 & 0.1004 & 0.0489 & 0.0360 \\
\hline Che mikiv & 0.0545 & 0.0964 & 0.0993 & 0.0938 & 0.0608 & 0.0443 \\
\hline Kyiv city & 0.0179 & 0.0185 & 0.0163 & 0.0162 & 0.0146 & 0.0119 \\
\hline Sevastopol city & 0.0042 & 0.0186 & 0.0085 & 0.0079 & & \\
\hline
\end{tabular}

* Results for Donetsk and Lugansk regions in parliamentary election 2014 are without uncontrolled territories 
and place-based factors. For instance, North-East Ukraine (Sumy and Chernihiv oblasts) has the vividly defined cluster of northern rayons and cities with stronger support for Communists and Party of Regions in 2002-2012 and Sylna Ukraina, Opposition Block, and Communist Party in 2014 (Figure 1). However, this cluster itself is not homogenous, and its borders were fluid during 2002-2014. Higher support for "pro-Russian and communist" parties in this neighboring part of two oblasts cannot be understood only by compositional characteristics. Seredyno-Budskyi rayon as an outlier in 2007-2014 has a lower number of ethnic Russians, while the highest number of Russian language speakers according to 2001 Census data. Putyvlskyi rayon having lower level of pro-Russian parties support than Seredyno-Budskyi has ethnic Russian majority (51.6\%) and domination of Russian language. On the south of Sumy oblast, Velykopysarivskyi rayon is second in the oblast by the number of ethnic Russians and third by Russian-speakers but is not so pro-Russian in electoral preferences as northern rayons of the oblast. The same is about Chernigiv oblast where the city of Chernihiv has more Russian language speakers than Semenivskyi rayon but vote more for "national-democratic" parties. Moreover, those rayons have a different history.
Putyvlskyi rayon was a part of Kursk gubernia in the Russian Empire. Semenivskyi, Novgorod-Siverskyi, and Seredyno-Budskyi rayons were not borderlands until the independence of Ukraine in 1991. Chernigiv gubernia also included Starodubshchyna, which is now part of the Russian Federation and those regions had only internal border with Starodubshchyna as well as only internal border in the times of USSR. Moreover, they have different patterns of political mobilization. For instance, Konotopskyi rayon in 2002 was mobilized by pro-Russian Progressive Socialists party based on local campaigning intensity and in following elections became not so supportive of pro-Russian parties.

In the case of Chernivtsi and Zakarpattya oblasts, outliers are rayons with the biggest share of ethnic minorities (Annexes A, C). However, it could be hasty and deceptive to interpret ethnicity as a crucial factor of voting preferences. In Beregivskyi rayon and Beregove city in Zakarpattya oblast, Hungarian minority constitutes the majority of the population as well as Romanian minority in Gertsaivskyi rayon and Moldovans minority in Novoselytskyi rayon of Chernivtsi oblast. Those four administrative units have the highest level of support for "pro-Russian" political parties and lowest support for "national-democratic".
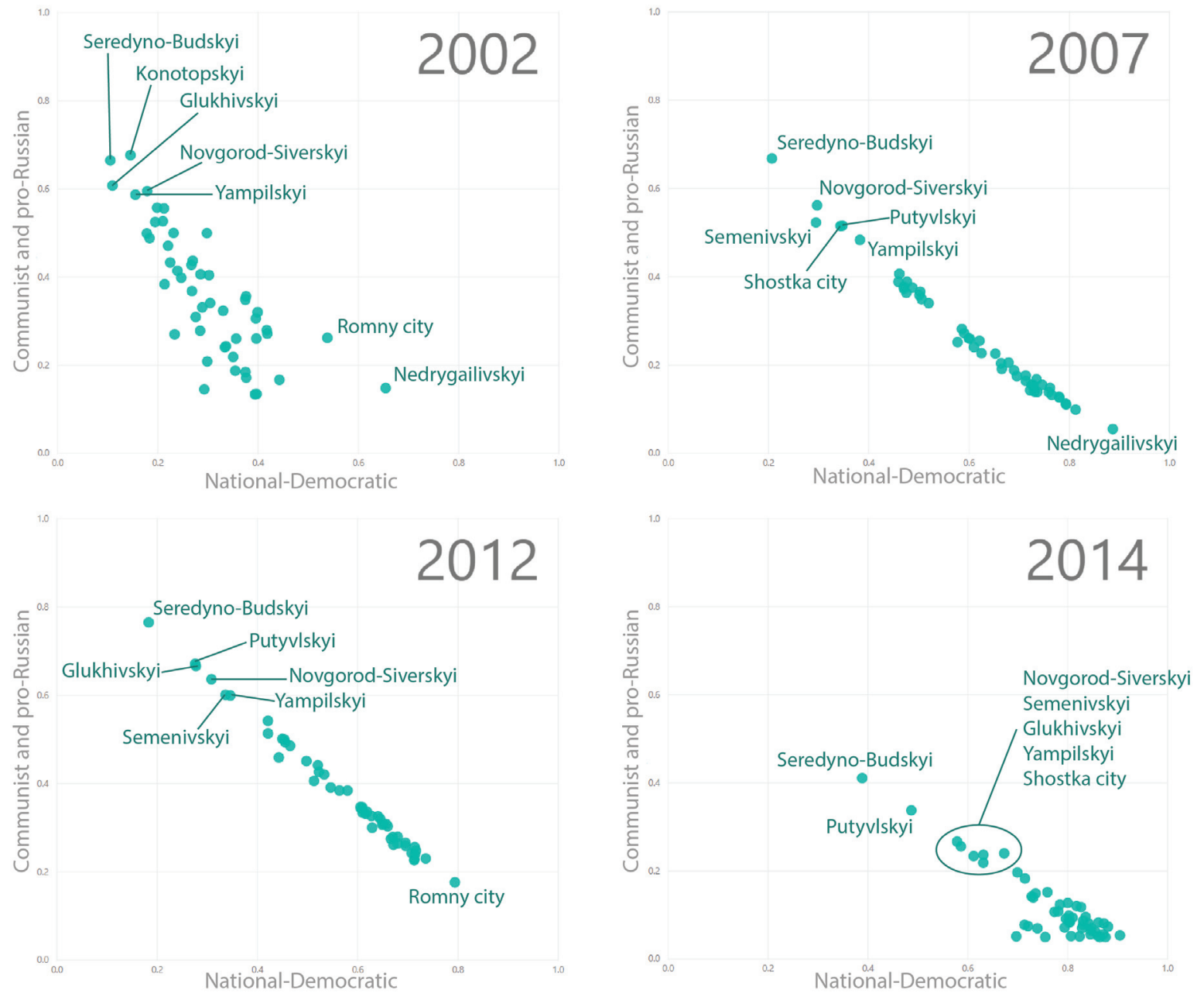

Figure 1. Intraregional variability of voting patterns in Sumy and Chernihiv oblasts in the parliamentary elections of 2002, 2007, 2012, 2014 


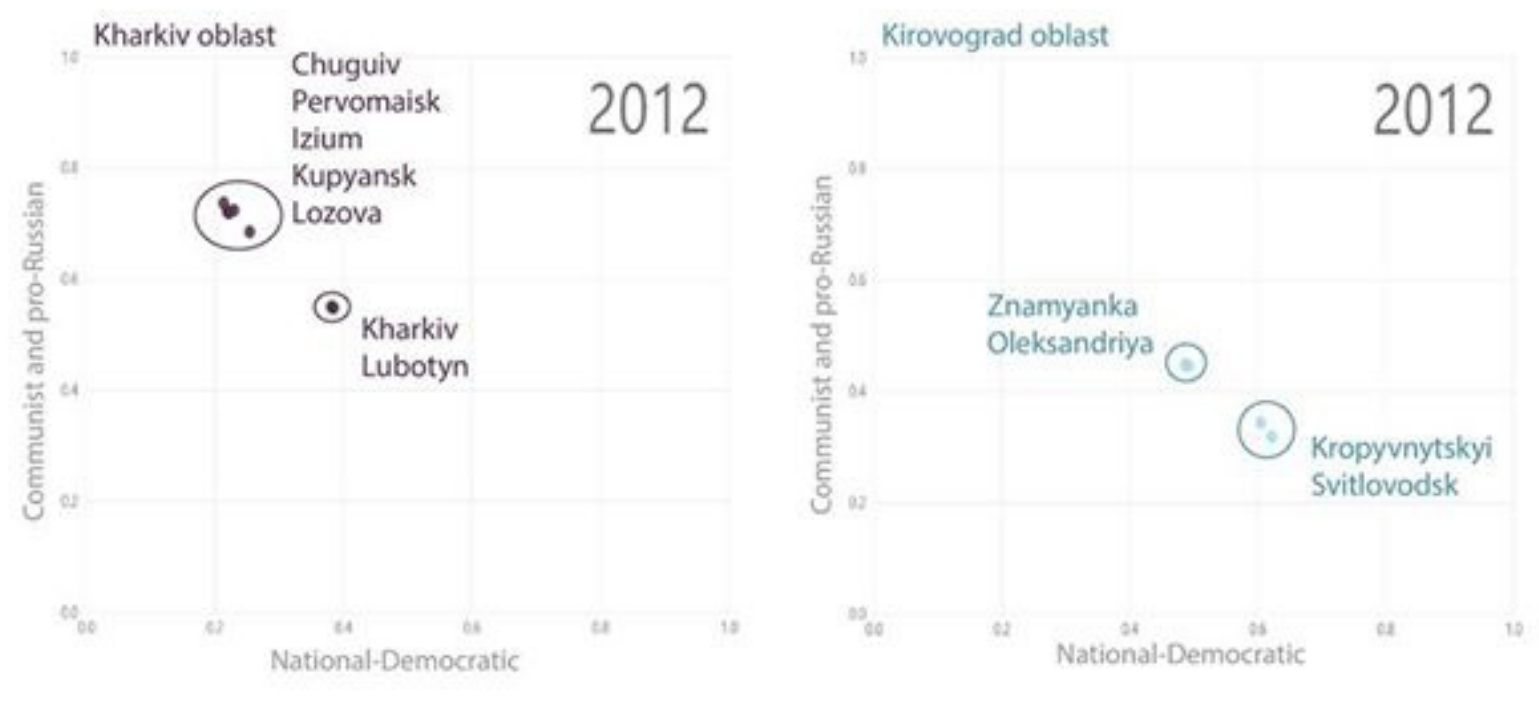

Figure 2. Intraregional variability of voting among cities with special status in Kharkiv and Kirovograd oblasts in 2012 parliamentary elections

However, Glybotskyi and Storozhynetskyi rayons with substantial Romanian minority $(45.3 \%$ and $36.8 \%$ respectively) in Chernivtsi oblast and Uzhgorodskyi (33.4\%) and Vynogradivskyi (26.2\%) with substantial Hungarian minority in Zakarpattya oblast have lower levels of support for pro-Russian parties than rayons with ethnic Ukrainian population like Sokyryanskyi and Novodnistrovsk city in Chernivtsi oblast and Volovetskyi and Khustskyi in Zakarpattya oblast (Annexes A, C). It rather questions local politics, the nature of electoral campaigning and mobilization of the electorate in places, which is understudied in Ukraine. For example, Zhytomyr oblast (Annex B) has no substantial differences in population composition but is among oblasts with highest intraregional variability in 2002-2012. Korosten was a Communists stronghold in Zhytomyr oblast for the 23 years before the Communist party of Ukraine was banned. However, substantial intraregional variability is not only in oblasts with highest deviations from the regional mean. Language, ethnicity, socioeconomic and other demographic compositional variables are also without explanatory power for such specific cases as intraregional variability of cities electoral behavior. For instance, in Kharkiv and Kirovograd oblasts cities there are more ethnic Russians and Russian language is more often used than in the periphery. However, in parliamentary elections 2006-2012, we can see (Figure 2) vivid divide within cities of those oblasts. Kropyvnytskyi and Svitlovodsk in Kirovograd oblast were more supportive of "nationaldemocratic" political parties as well as Kharkiv and Lubotyn cities in Kharkiv oblast.

\section{Place and region as a context for the interpretation of electoral results in Ukraine}

Place and region can be the contexts for causal interpretations of electoral results as well as a comparative understanding of electoral behavior. Following Paasi (1991, 2003) understanding of regions as of longer historical duration comparing to places, we found that in Ukraine historical region of Galicia has the lowest level of intraregional variability in the 2002-2014 parliamentary election. Only Turkivskyi rayon in Lviv oblast is an outlier in 2002 parliamentary elections because of the higher level of support for For United Ukraine party. However, if we compare electoral outcomes of cities in Galicia to cities in historical Volyn region, we can see that Galician cities have higher levels of support for pro-Russian and Communist parties than region's periphery (Figure 3) despite having higher levels of support for "national-democratic" parties than Volhynian cities. Contrarily, in Volyn region, cities have higher levels of support for "national-democratic" parties (Figure 3) and especially far-right parties than the region's periphery. Moreover, Johnston (1991) states that regions are the deliberate product of those with power. We can see that administrative elites dominate traditional regionalist elites in Ukraine. At the same time, historical borders can be revealed on electoral maps in time-specific contexts. For example, the northern part of Galician Ternopil oblast is historical Volyn. In 2002-2007 as well as in 2014 parliamentary elections, it did not demonstrate essential differences in voting behavior from Galician part of the oblast. However, in 2012 parliamentary election rayons parts of which are historical Volyn (were not part of Austrian Empire in contrast to Galician part of the oblast) had more "pro-Russian and communist" patterns of voting (Figure 3). However, electoral campaigning in Ukraine is more often following administrative boundaries than historical borders.

Moreover, places and regions patterns of voting behavior in Ukraine are fluid. Consequently, they could be better understood analyzing voting patterns dynamics and not only cross-sectional dimension. We analyzed electoral preferences trajectories of rayons and cities with special administrative status in Ukraine and revealed that dynamics of electoral support for "nationaldemocratic" or "communists and pro-Russian" political 


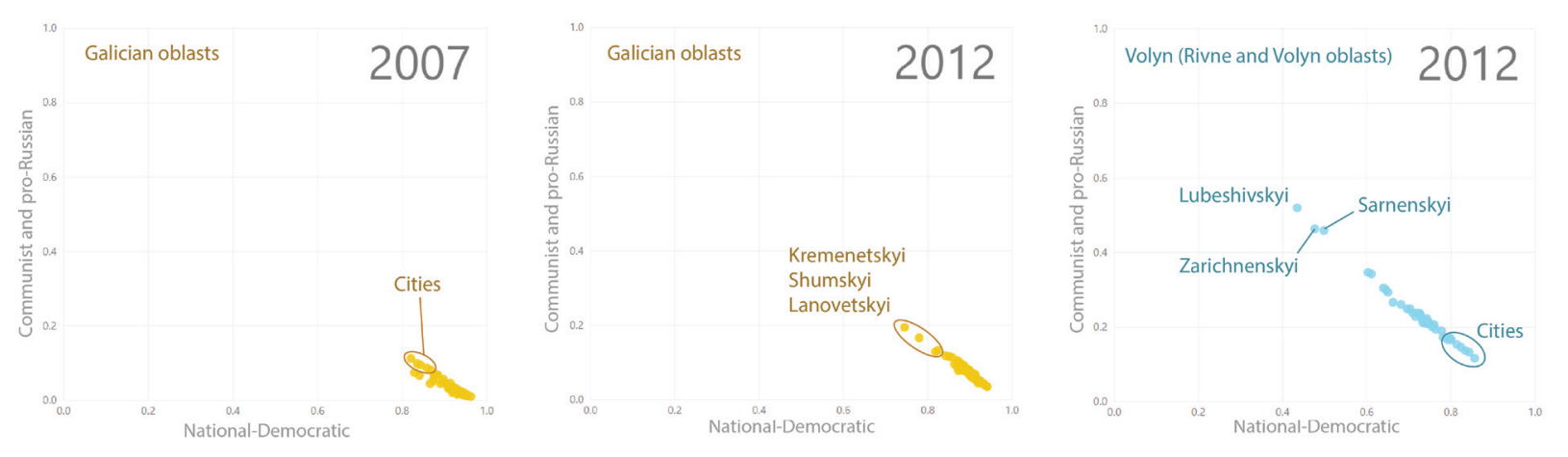

Figure 3. Electoral preferences of cities and rayons in 2007 and 2012 parliamentary elections in Galician and Volhynian oblasts
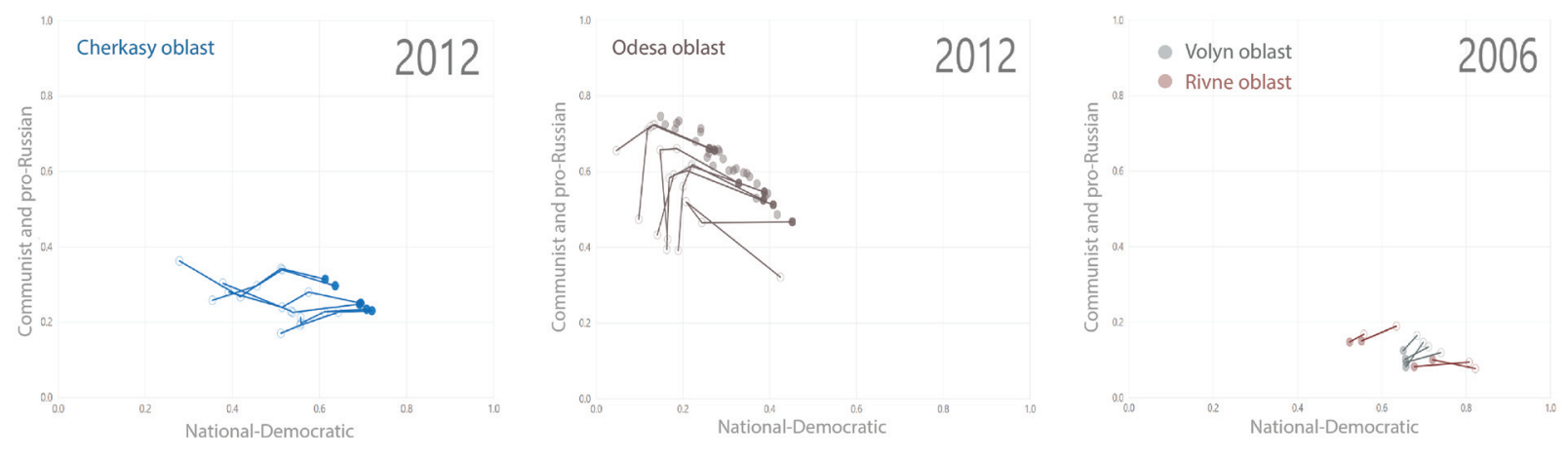

Figure 4. Difference in electoral preferences dynamics in cities with special status in Cherkasy (2002-2012), Odesa (2002-2012), Volyn, and Rivne oblasts (2002-2006)
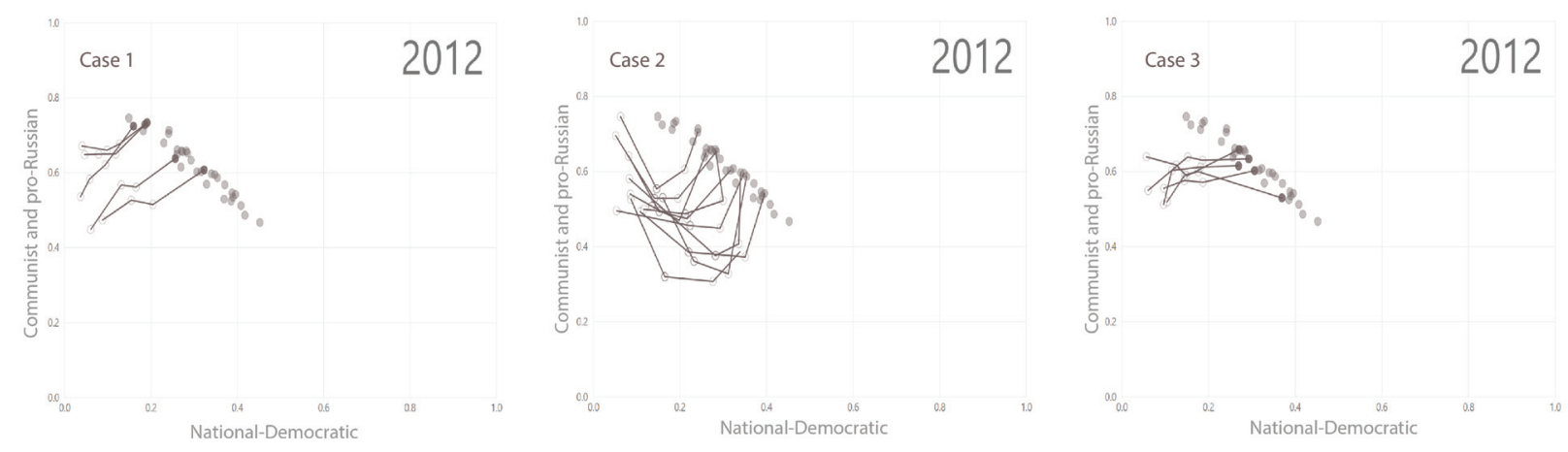

Figure 5. Groups of rayons in Odesa oblast based on their electoral preferences dynamics in parliamentary elections 2002, 2006, 2007, and 2012

parties in cities is region-specific, which reveals the role of regions as contexts for electoral behavior in different places. For instance, most of the cities in Odessa region dramatically shifted to pro-Russian parties support in 2002-2006, have no essential dynamics in 2006-2007, and turned to "national-democratic" in 2007-2012 (Figure 4) and continued this trend in 2014. Contrarily, cities in Cherkasy region (as well as Vinnytsya and Khmelnytskyi regions) were constantly increasing "national-democratic" electoral preferences in 20022012 (Figure 4), which also continued from 2012 to 2014 elections. Cities in historical Volyn (simplified to Volyn and Rivne oblasts), having similar to Cherkasy, Vinnytsya and Khmelnytskyi oblasts more "nationaldemocratic" voting preferences, in 2002-2006 decreased their support for "national-democratic" parties but did not increase support for pro-Russian forces (Figure 4), which means that those votes were distributed between "third" parties or were not mobilized and appeared in non-voters category.

Electoral preferences dynamics is essential not only for cities in regions showing how important are regions as interpretative contexts but also for rayons as the periphery of oblasts. Rayons as geographical places could be grouped not only based on their electoral preferences in particular elections but also based on the dynamics of their preferences. For instance, Odesa oblast rayons electoral preferences trajectories between "nationaldemocratic" and "communist and pro-Russian" poles in 2002-2012 parliamentary elections show three distinct cases, which do not strictly follow territorial proximity. Rayons in the first case (Figure 5) where constantly 

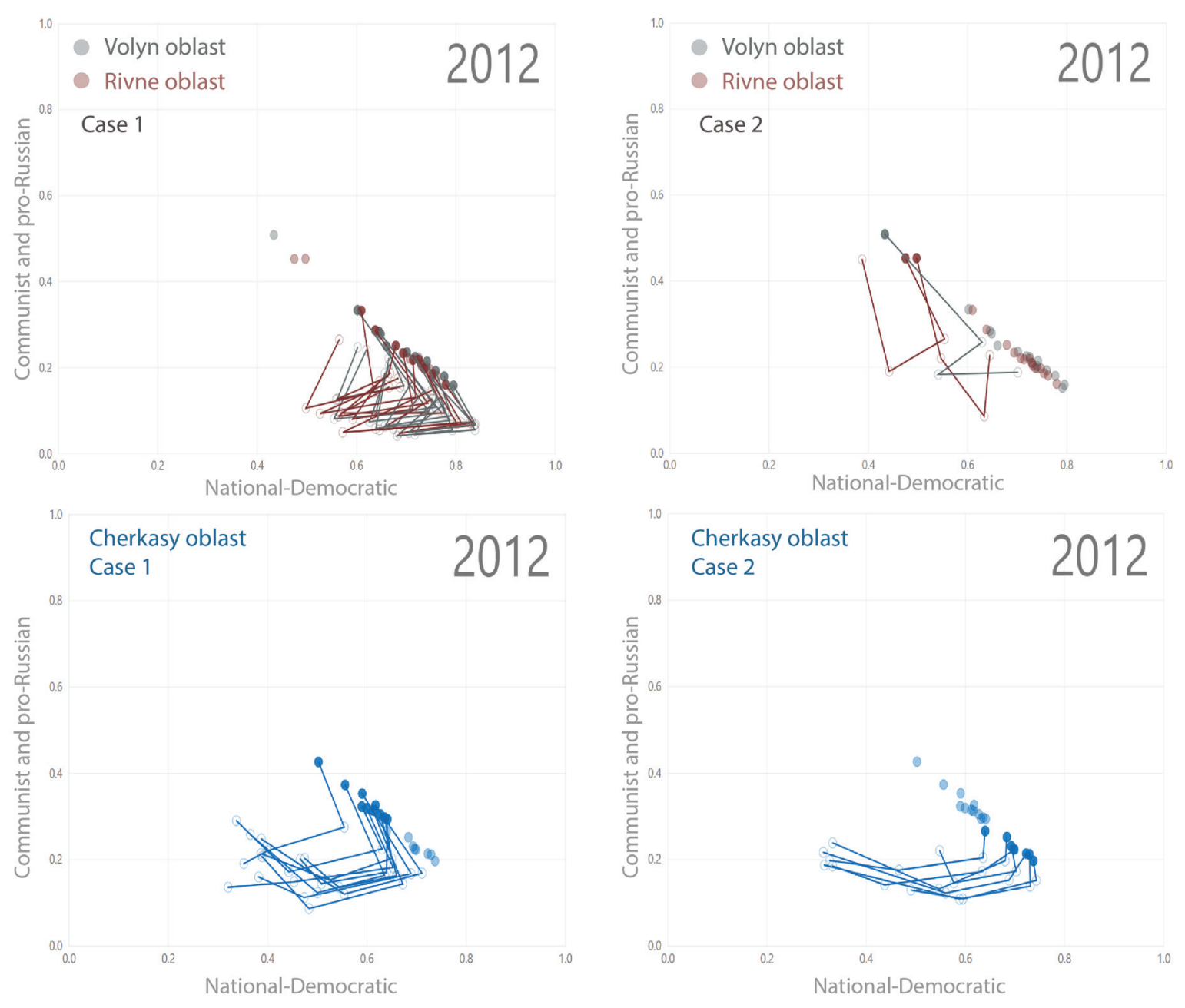

Figure 6. Electoral preferences trajectories in parliamentary elections from 2002 to 2012 in Volyn, Rivne, and Cherkasy oblasts

polarized shifting from the vote for "third" parties to increase in support for both poles. The second case shows those rayons that in the wave of Orange revolution dramatically decreased support of "pro-Russian" parties and Communists, but then were polarized back in 20062012. The third case reveals rayons, which despite some instability of voting patterns were increasing "nationaldemocratic" parties support without changes in support for "pro-Russian and Communists" parties.

Analysis of electoral preferences trajectories also reveals regional contexts as well as intraregional variability and place-specific contexts of changes in voting behavior. For example, in the case of historical Volyn (limited to Rivne and Volyn oblasts for analysis), almost all rayons had similar electoral preferences trajectory in 2002-2012 parliamentary elections despite intraregional variability in electoral outcomes. Only Lubeshivskyi, Zarichnenskyi, and Sarnenskyi rayons had place-specific voting patterns, which are bounded by administrative borders. The case of Cherkasy oblast shows that the way how parties structure regions territorially may differ in time. Rayons of the oblast where following similar patterns in 2002-2007, but from 2007 to 2012 their electoral trajectories essentially changed. One group of regions demonstrated a substantial shift to support of the Party of Regions and Communists, while the other group despite the existence of that turn in support of proRussian parties had lower levels of change (Figure 6).

Sometimes place-specific voting is only temporary phenomena as in the case of Pavlograd and Ternivka cities in Dnipropetrovsk oblast and Teplodar city in Odesa oblast vote for Yuliya Tymoshenko's Block in 2002 parliamentary elections and when turning back to their region's average patterns of voting. In other cases, cities or rayons in their administrative borders have permanent voting patterns. For example, Nikopol city in Dnipropetrovsk oblast (Figure 7) in 2002-2014 is an outlier with the stronger support of "nationaldemocratic" parties as well as Yuzhnoukrainsk city in Mykolaiv oblast. At the same time, some cities demonstrate such similar electoral preferences dynamics that they might be understood as the same electoral space and one place with specific voting behavior. Two big cities, Dnipro and Kamyanske (before decommunization Dnipropetrovsk and Dniprodzerzhynsk) are a great example (Figure 7).

Electoral dynamics at rayon and city levels reveals how political parties structure territory of the country. That process of political structuration has many aspects that are not in the focus of this paper. However, we can 

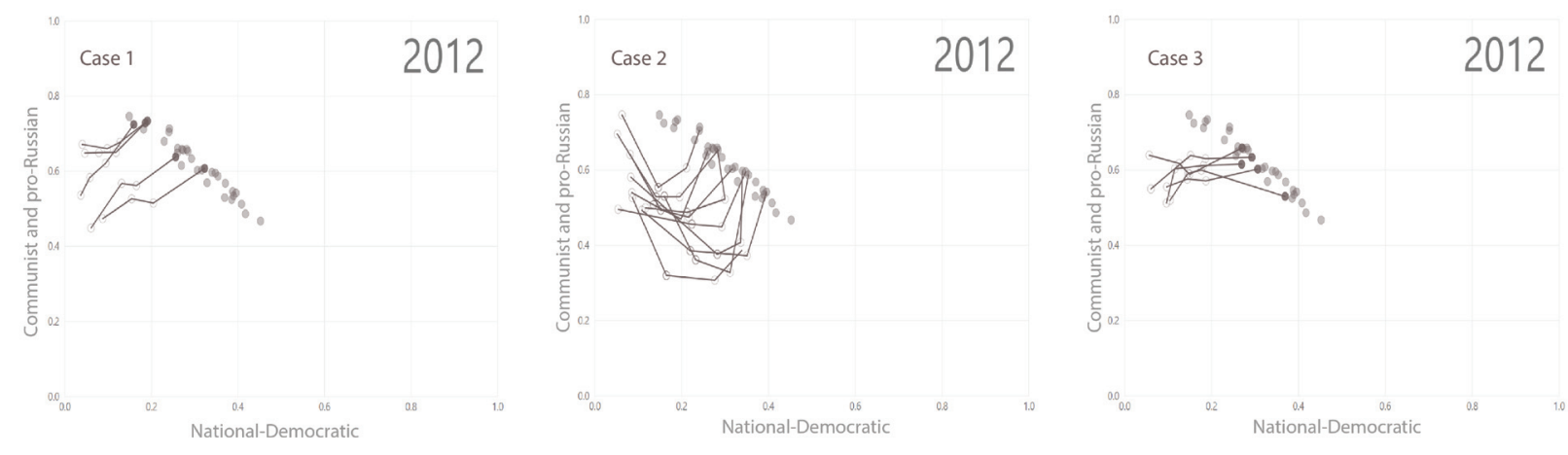

Figure 7. Electoral preferences trajectories of Dnipro and Kamyanske cities (2002-2014) and Nikopol city (2002-2012)
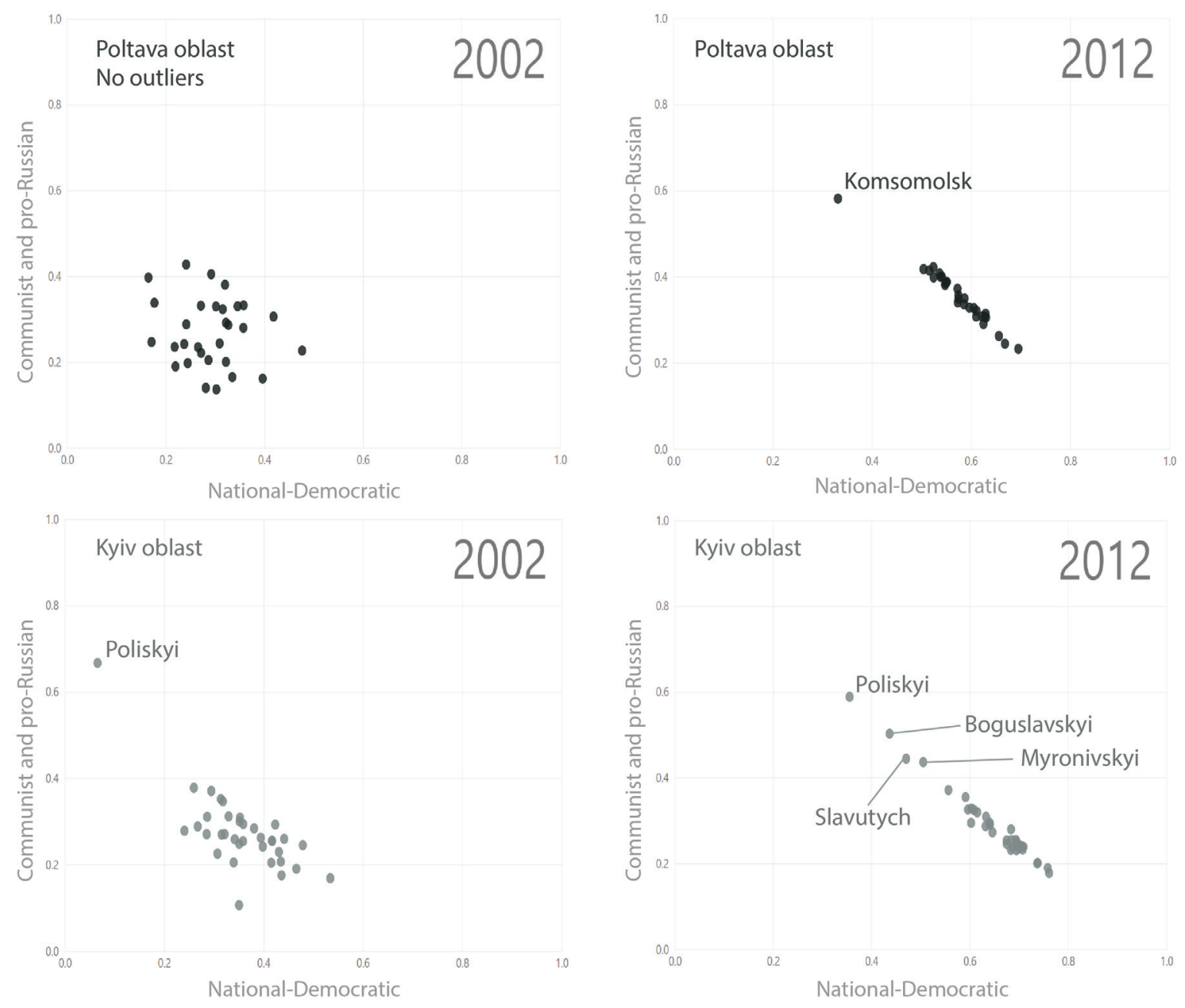

Figure 8. Territorial structuration and polarization of intraregional voting patterns in 2002-2012 in Kyiv and Poltava oblasts

admit that in 2002-2012 all oblasts of Ukraine had vivid changes and shifts in the territorial structure of voting, which were not changing intraregional variability but grouped rayons and cities differently, which is more polarized and less dispersed. For instance, in the case of Kyiv and Poltava oblasts (Figure 8) those changes in the structure of support are visible. Moreover, in Poltava case, it resulted in the appearance of Komsomolsk city as an outlier and consequently a place with specific voting context. In contrast, Poliskyi rayon in Kyiv oblast was a stable outlier for the 2002-2012 period and remained such in 2014. At the same time, the polarization of political beliefs in the oblast in 20022012 resulted in the turn of specific rayons and cities to stronger support of the Party of Regions (Boguslavskyi, Myronivskyi, Slavutych). Nature of such turn was not in the focus of this paper but is of great interest for electoral geography studies of Ukraine. 


\section{Discussion and conclusion}

Intraregional variability of electoral preferences in Ukraine in 2002-2014 reveals that there are persistent outliers as well as groups of rayons with different from the rest of the region political beliefs, which can be understood as unique places for further electoral studies. Zakarpattya, Chernivtsi, Chernigiv, Sumy, and Zhytomyr oblasts had the highest average intraregional deviations in 2002-2012. While Zhytomyr and Zakarpattya homogenized in 2014 parliamentary elections, Chernivtsi, Chernigiv, and Sumy oblasts remained essentially divided in their electoral preferences. Other oblasts of Ukraine also have substantial intraregional variations. The most vivid are outliers that constitute administratively bounded places with unique voting patterns. Among them Komsomolsk city in Poltava (2006-2014), Nikopol city in Dnipropetrovsk (20022014), Gertsaivskyi rayon in Chernivtsi (2002-2014), Seredyno-Budskyi (2002-2014) and Nedrygailivskyi (2002-2007) in Sumy, Poliskyi in Kyiv (2002-2012), Lubeshivskyi in Volyn (2006-2014), Zarichnenskyi (2002-2014), Sarnenskyi (2007-2012), and Rokytnivskyi rayon (2002) in Rivne, Turkivskyi (2002) in Lviv oblast. Moreover, the study shows that cities electoral behavior and dynamics is region-specific. Cities in Galician oblasts demonstrate higher (not substantially but higher) level of support for "pro-Russian" parties and Communists in 2002-2012 than region periphery, while cities in Volyn (simplified to Volyn and Rivne oblasts) have stronger support for "national-democratic" parties and nationalists in comparison to regions periphery. Electoral preferences dynamics also matters. Cities in Odesa oblast have distinctive electoral trajectories from cities in Cherkasy, Vinnytsya and Khmelnytskyi oblasts. Cities in Volyn region having the same trend as cities in Cherkasy, Vinnytsya, and Khmelnytskyi in 2006-2014 had a different electoral trajectory in 2002-2006. Parties structure Ukrainian electorate not only at the macro level and East-West scale but also at the intraregional dimension. The study reveals that different rayons in different oblasts of Ukraine have significant variations of electoral behavior dynamics. At the same time, there are clusters of rayons and cities that have similar voting patterns. It reveals how local places give a response to regional and national contexts of voting.

Places and regions in electoral geography are timespace configurations, which are not obviously permanent and could emerge as temporary phenomena. Reasons why the various time-contexts result in different spatial structures of voting behavior and, at the same time, why some places have stable patterns of electoral preferences cannot be revealed only by correlation-based analysis of compositional variables of those areas. Parties are structuring territory of the country (Agnew, 2002) and nature of electoral campaigns, party politics and local political processes is of great interest for further electoral studies of the territorial differences of political beliefs in Ukraine. Every division of the territory of the country for the study purposes is arbitrary; consequently, scholars rather should primarily pay attention how the territory of the country is structured by electoral outcomes at the lowest possible level and in dynamics to reveal region- and place-specific patterns of voting. Regions and places themselves are not homogenous, and they could be experienced differently by different social groups (Massey, 1993). However, they create unique contexts for electoral choices to be made.

\section{References:}

1. Agnew, J. Mapping Politics: How Context Counts in Electoral Geography. Political Geography, vol. 15, no. 2, 1996, pp. 129-46, doi:10.1016/0962-6298(95)00076-3.

2. Agnew, J. Regions on the Mind Does Not Equal Regions of the Mind. Progress in Human Geography, vol. 23, no. 1, Sage PublicationsSage CA: Thousand Oaks, CA, Mar. 1999, pp. 91-96, doi:10.1191/030913299677849788.

3. Barrington, L. W. The Geographic Component of Mass Attitudes in Ukraine. Post-Soviet Geography and Economics, vol. 38, no. 10, 1997, pp. 601-14, doi:10.1080/10889388.1997.10641065.

4. Barrington, L. W., Herron, E. S. One Ukraine or Many? Regionalism in Ukraine and Its Political Consequences. Nationalities Papers, vol. 32, no. 1, 2004, pp. 53-86, doi:10.1080/0090599042000186179.

5. Birch, S., Wilson A. The Ukrainian Parliamentary Elections of 1998. Electoral Studies, vol. 18, no. 2, 1999, pp. 276-82, doi:10.1016/S0261-3794(98)00050-X.

6. Birch, S. Interpreting the Regional Effect in Ukrainian Politics. Europe-Asia Studies, vol. 52, no. 6, 2000, pp. 1017-41, doi:10.1080/09668130050143815.

7. Brooks, C., et al. Cleavage-Based Voting Behavior in Cross-National Perspective Evidence from Six Postwar Democracies. Social Science Research, vol. 35, 2006, pp. 88-128.

8. Clem, R. S., Craumer, P. R. Shades of Orange: The Electoral Geography of Ukraine's 2004 Presidential Elections. Eurasian Geography and Economics, vol. 46, no. 5, 2005, pp. 364-85, doi:10.2747/1538-7216.46.5.364.

9. Clem, R. S., Craumer, P. R. Orange, Blue and White, and Blonde: The Electoral Geography of Ukraine's 2006 and 2007 Rada Elections. Eurasian Geography and Economics, vol. 49, no. 2, 2008, pp. 127-51, doi:10.2747/15397216.49.2.127.

10. Colton, T. J. An Aligning Election and the Ukrainian Political Community. East European Politics \& Societies, vol. 25, no. 1, 2011, pp. 4-27, doi:10.1177/0888325410388561.

11. Gentile, M. West Oriented in the East-Oriented Donbas: A Political Stratigraphy of Geopolitical Identity in Luhansk, Ukraine. Post-Soviet Affairs, vol. 31, no. 3, 2015, pp. 201-23, doi:10.1080/1060586X.2014.995410.

12. Gilbert, A. The New Regional Geography in English and French-Speaking Countries. Progress in 
Human Geography, vol. 12, no. 2, Sage PublicationsSage CA: Thousand Oaks, CA, June 1988, pp. 208-28, doi:10.1177/030913258801200203.

13. Haydukiewicz, L. Historical and Geographic Regionalization versus Electoral Geography. Procedia - Social and Behavioral Sciences, vol. 19, 2011, pp. 98-111, doi:10.1016/j.sbspro.2011.05.112.

14. Hinich, M. J., et al. Ukraine's 1998 Parliamentary Elections: A Spatial Analysis. Post-Soviet Affairs, vol. 15, no. 2, 1999, pp. 149-85, doi:10.1080/1060586X.1999.10641468.

15. Holdar, S. Torn between East and West - the Regional Factor in Ukrainian Politics. Post-Soviet Geography, vol. 36, no. March 2015, pp. 112-32, doi:10.1080/10605851.1995.10640982.

16. Johnston, R. J. A Question of Place: Exploring the Practice of Human Geography. 1991, https://philpapers.org/ rec/JOHAQO.

17. Katchanovski, I. East or West? Regional Political Divisions in Ukraine since the 'Orange Revolution' and the 'Euromaidan. American Political Science Association, 2014, p. 43, doi:10.1017/CBO9781107415324.004.

18. Katchanovski, I. Regional Political Divisions in Ukraine in 1991-2006'. Nationalities Papers, vol. 34, no. 5, 2006, pp. 507-32, doi:10.1080/00905990600952939.

19. Khmelko, I. S., et al. Regionalism in Ukraine and Its Role in the Ukrainian Politics. Journal of East European and Asian Studies, vol. February, 2011, pp. 93-110.

20. Kubicek, P. What Happened to the Nationalists in Ukraine? Nationalism and Ethnic Politics, vol. 5, no. 1, 1999, pp. 29-45, doi:10.1080/13537119908428553.

21. Liber, G. O. Imagining Ukraine: Regional Differences and the Emergence of an Integrated State Identity, 1926-1994. Nations and Nationalism, vol. 4, no. 2, 1998, pp. 187-206, doi:10.1111/j.1354-5078.1998.00187.x.

22. Massey, D. Power-Geometry and a Progressive Sense of Place. Mapping the Future. Local Cultures, Global Change, edited by John Bird et al., Routledge, 1993, pp. 59-69.

23. Murphy, A. B. Rethinking Multi-Level Governance in a Changing European Union: Why Metageography and Territoriality Matter. GeoJournal, vol. 72, no. 1-2, Springer Netherlands, June 2008, pp. 7-18, doi:10.1007/s10708008-9161-9.

24. O'Loughlin, J. The Regional Factor in Contemporary Ukrainian Politics: Scale, Place, Space, or Bogus Effect? Post-Soviet Geography and Economics, vol. 42, 2001, pp. 1-33, doi:10.1080/10889388.2001.10641161.

25. Osipian, A. L., Osipian A. L. Regional Diversity and Divided Memories in Ukraine: Contested Past as Electoral Resource, 2004-2010. East European Politics \& Societies, vol. 26, 2012, pp. 616-42, doi:10.1177/0888325412447642.

26. Paasi, A. Deconstructing Regions: Notes on the Scales of Spatial Life. Environment and Planning A, vol. 23, no. 2, SAGE PublicationsSage UK: London, England, Feb. 1991, pp. 239-56, doi:10.1068/a230239.

27. Paasi, A. Bounded Spaces in the Mobile World: Deconstructing 'Regional Identity. Tijdschrift Voor Economische En Sociale Geografie, vol. 93, no. 2, 2002, pp. 137-48.

28. Paasi, A. Deconstructing Regions: Notes on the Scales of Spatial Life. Environment and Planning A, vol. 23, no. 2, 1991, pp. 239-56, doi:10.1068/a230239.

29. Paasi, A. Region and Place: Regional Identity in Question. Progress in Human Geography, vol. 27, no. 4, 2003, pp. 475-85, doi:10.1191/0309132503ph439pr.

30. Paasi, A. Regional Planning and the Mobilization of 'Regional Identity': From Bounded Spaces to Relational Complexity. Regional Studies, vol. 47, no. 8, 2013, pp. 1206-19, doi:10.1080/00343404.2012.661410.

31. Paasi, A. The Institutionalization of Regions: A Theoretical Framework for Understanding the Emergence of Regions and the Constitution of Regional Identity. Fennia - International Journal of Geography, vol. 164, no. 1, 1986, pp. 105-46, https://fennia.journal.fi/article/view/9052.

32. Painter, J. Cartographic Anxiety and the Search for Regionality. Environment and Planning A, vol. 40, no. 2, SAGE PublicationsSage UK: London, England, Feb. 2008, pp. 342-61, doi:10.1068/a38255.

33. Peisakhin, L. In History's Shadow: Do Formal Institutions Leave a Cultural Legacy? EPSA 2013 Annual General Conference, 2013, p. 40, http://ssrn.com/abstract=2224765.

34. Peisakhin, L. Long Run Persistence of Political Attitudes and Behavior: A Focus on Mechanisms. CES Conference, 2013, https://ces.confex.com/ces/2013/webprogram/Paper4052.html.

35. Riabchuk, M. 'Two Ukraines' Reconsidered: The End of Ukrainian Ambivalence? Studies in Ethnicity and Nationalism, vol. 15, no. 1, 2015, pp. 138-56, doi:10.1111/sena.12120.

36. Rodgers, P. W. Contestation and Negotiation: Regionalism and the Politics of School Textbooks in Ukraine's Eastern Borderlands. Nations and Nationalism, vol. 12, no. 4, 2006, pp. 681-97, doi:10.1111/j.14698129.2006.00262.x.

37. Sayer, A. The 'New' Regional-Geography and Problems of Narrative. Environment and Planning D - Society \& Space, vol. 7, no. 3, 1989, pp. 253-76, doi:10.1068/d070253.

38. Schmitt-Egner, P. The Concept of 'Region': Theoretical and Methodological Notes on Its Reconstruction. Journal of European Integration, vol. 24, no. 3, 2002, pp. 179-200, doi:10.1080/07036330270152196.

39. Shevel, O. The Parliamentary Elections in Ukraine, October 2014. Electoral Studies, vol. 39, no. October 2014, Elsevier, 2015, pp. 159-63, doi:10.1016/j.electstud.2015.03.015.

40. Stölting, E., et al. New Regional Identities and Strategic Essentialism, 2005.

41. Von Löwis, S. Phantom Borders in the Political Geography of East Central Europe: An Introduction. Erdkunde, vol. 69, no. 2, 2015, pp. 99-106, doi:10.3112/erdkunde.2015.02.01. 


\section{Список використаних джерел:}

1. Agnew J. Mapping Politics: How Context Counts in Electoral Geography / J. Agnew // Political Geography. 1996. - Vol. 15. - No. 2. - Pp. 129-146. doi:10.1016/0962-6298(95)00076-3.

2. Agnew J. Regions on the Mind Does Not Equal Regions of the Mind / J. Agnew // Progress in Human Geography. - 1999. - Vol. 23. - No. 1. - Sage Publications Sage CA: Thousand Oaks, CA, Mar. - Pp. 91-96. doi:10.1191/030913299677849788.

3. Barrington L. W. The Geographic Component of Mass Attitudes in Ukraine / L. W. Barrington // Post-Soviet Geography and Economics. - 1997. - Vol. 38. - No. 10. - Pp. 601-614, doi:10.1080/10889388.1997.10641065.

4. Barrington L. W. One Ukraine or Many? Regionalism in Ukraine and Its Political Consequences. / L. W. Barrington, E. S. Herron // Nationalities Papers. - 2004. - Vol. 32. - No. 1. - Pp. 53-86. doi:10.1080/0090599042000186179.

5. Birch S. The Ukrainian Parliamentary Elections of 1998 / S. Birch, A. Wilson // Electoral Studies. - 1999. Vol. 18. - No. 2. - Pp. 276-82. doi:10.1016/S0261-3794(98)00050-X.

6. Birch S. Interpreting the Regional Effect in Ukrainian Politics / S. Birch // Europe-Asia Studies. - 2000. - Vol. 52. No. 6. - Pp. 1017-1041. doi:10.1080/09668130050143815.

7. Brooks C. Cleavage-Based Voting Behavior in Cross-National Perspective Evidence from Six Postwar Democracies / C. Brooks et al. // Social Science Research. - 2006. - Vol. 35. - Pp. 88-128.

8. Clem R. S. Shades of Orange: The Electoral Geography of Ukraine's 2004 Presidential Elections / R. S. Clem, P. R. Craumer // Eurasian Geography and Economics. - 2005. - Vol. 46. No. 5. - Pp. 364-385. doi:10.2747/15387216.46.5.364.

9. Clem R. S. Orange, Blue and White, and Blonde: The Electoral Geography of Ukraine's 2006 and 2007 Rada Elections / R. S. Clem, P. R. Craumer // Eurasian Geography and Economics. - 2008. - Vol. 49. - No. 2. - Pp. 127-151. doi:10.2747/15397216.49.2.127.

10. Colton T. J. An Aligning Election and the Ukrainian Political Community / T. J. Colton // East European Politics \& Societies. - 2011. - Vol. 25. - No. 1. - Pp. 4-27, doi:10.1177/0888325410388561.

11. Gentile M. West Oriented in the East-Oriented Donbas: A Political Stratigraphy of Geopolitical Identity in Luhansk, Ukraine / M. Gentile // Post-Soviet Affairs. - 2015. - Vol. 31. - No. 3. - Pp. 201-223. doi:10.1080/1060586X.2014.995410.

12. Gilbert A. The New Regional Geography in English and French-Speaking Countries / A. Gilbert // Progress in Human Geography. - 1988. - Vol. 12. - No. 2. - Pp. 208-228. doi:10.1177/030913258801200203.

13. Haydukiewicz L. Historical and Geographic Regionalization versus Electoral Geography / L. Haydukiewicz // Procedia - Social and Behavioral Sciences. - 2011. - Vol. 19. - Pp. 98-111. doi:10.1016/j.sbspro.2011.05.112.

14. Hinich M. J. Ukraine's 1998 Parliamentary Elections: A Spatial Analysis / M. J. Hinich et al. // Post-Soviet Affairs. - 1999. - Vol. 15. - No. 2. - Pp. 149-185, doi:10.1080/1060586X.1999.10641468.

15. Holdar S. Torn between East and West - the Regional Factor in Ukrainian Politics / S. Holdar // Post-Soviet Geography. - 2015. - Vol. 36. - No. March 2015. - Pp. 112-132, doi:10.1080/10605851.1995.10640982.

16. Johnston R. J. A Question of Place: Exploring the Practice of Human Geography / R. J. Johnston. - 1991, https://philpapers.org/rec/JOHAQO.

17. Katchanovski I. East or West? Regional Political Divisions in Ukraine since the 'Orange Revolution' and the 'Euromaidan / I. Katchanovski // American Political Science Association. - 2014. - 43 p. doi:10.1017/CBO9781107415324.004.

18. Katchanovski I. Regional Political Divisions in Ukraine in 1991-2006' / I. Katchanovski // Nationalities Papers. - 2006. - Vol. 34. - No. 5. - Pp. 507-532, doi:10.1080/00905990600952939.

19. Khmelko I. S. Regionalism in Ukraine and Its Role in the Ukrainian Politics / I. S. Khmelko et al. // Journal of East European and Asian Studies. - 2011. - Vol. February, 2011. - Pp. 93-110.

20. Kubicek P. What Happened to the Nationalists in Ukraine? / P. Kubicek // Nationalism and Ethnic Politics. - 1999. - Vol. 5. - No. 1. - Pp. 29-45, doi:10.1080/13537119908428553.

21. Liber G. O. Imagining Ukraine: Regional Differences and the Emergence of an Integrated State Identity, 1926-1994 / G. O. Liber // Nations and Nationalism. - 1998. - Vol. 4. - No. 2. - Pp. 187-206. doi:10.1111/j.1354-5078.1998.00187.x.

22. Massey D. Power-Geometry and a Progressive Sense of Place. Mapping the Future / D. Massey / Local Cultures, Global Change, edited by J. Bird et al. - Routledge, 1993. - Pp. 59-69.

23. Murphy A. B. Rethinking Multi-Level Governance in a Changing European Union: Why Metageography and Territoriality Matter / A. B. Murphy // GeoJournal. - 2008. - Vol. 72. - No. 1-2. - Pp. 7-18. doi:10.1007/s10708-008-9161-9.

24. O'Loughlin J. The Regional Factor in Contemporary Ukrainian Politics: Scale, Place, Space, or Bogus Effect? / J. O’Loughlin // Post-Soviet Geography and Economics. - 2001. - Vol. 42. - Pp. 1-33. doi:10.1080/10889388.2001.1 0641161.

25. Osipian, A. L. Regional Diversity and Divided Memories in Ukraine: Contested Past as Electoral Resource, 2004-2010 / A. L Osipian, A. L. Osipian // East European Politics \& Societies. - 2012. - Vol. 26. - Pp. 616-642, doi:10.1177/0888325412447642.

26. Paasi A. Deconstructing Regions: Notes on the Scales of Spatial Life / A. Paasi // Environment and Planning A. - 1991. - Vol. 23. - No. 2. - Pp. 239-256. doi:10.1068/a230239.

27. Paasi A. Bounded Spaces in the Mobile World: Deconstructing 'Regional Identity / A. Paasi // Tijdschrift Voor 
Economische En Sociale Geografie. - 2002. - Vol. 93. - No. 2. - Pp. 137-148.

28. Paasi A. Deconstructing Regions: Notes on the Scales of Spatial Life / A. Paasi // Environment and Planning A. - 1991. - Vol. 23. - No. 2. - Pp. 239-256, doi:10.1068/a230239.

29. Paasi A. Region and Place: Regional Identity in Question / A. Paasi // Progress in Human Geography. - 2003.

- Vol. 27. - No. 4. - Pp. 475-85, doi:10.1191/0309132503ph439pr.

30. Paasi A. Regional Planning and the Mobilization of 'Regional Identity': From Bounded Spaces to Relational Complexity / A. Paasi // Regional Studies. - 2013. - Vol. 47. - No. 8. - Pp. 1206-1219. doi:10.1080/00343404.2012.661410.

31. Paasi A. The Institutionalization of Regions: A Theoretical Framework for Understanding the Emergence of Regions and the Constitution of Regional Identity / A. Paasi // Fennia - International Journal of Geography. - 1986. Vol. 164. - No. 1. - Pp. 105-146.

32. Painter J. Cartographic Anxiety and the Search for Regionality / J. Painter // Environment and Planning A. 2008. - Vol. 40. - No. 2. - Pp. 342-361. doi:10.1068/a38255.

33. Peisakhin L. In History's Shadow: Do Formal Institutions Leave a Cultural Legacy? / L. Peisakhin // EPSA

2013 Annual General Conference, 2013. -40 p., http://ssrn.com/abstract=2224765.

34. Peisakhin L. Long Run Persistence of Political Attitudes and Behavior: A Focus on Mechanisms / L. Peisakhin // CES Conference, 2013, https://ces.confex.com/ces/2013/webprogram/Paper4052.html.

35. Riabchuk M. 'Two Ukraines' Reconsidered: The End of Ukrainian Ambivalence? / M. Riabchuk // Studies in Ethnicity and Nationalism. - 2015. - Vol. 15. - No. 1. - Pp. 138-156, doi:10.1111/sena.12120.

36. Rodgers P. W. Contestation and Negotiation: Regionalism and the Politics of School Textbooks in Ukraine's Eastern Borderlands / P. W. Rodgers // Nations and Nationalism. - 2006. - Vol. 12. - No. 4. - Pp. 681-697. doi:10.1111/ j.1469-8129.2006.00262.x.

37. Sayer A. The 'New' Regional-Geography and Problems of Narrative / A. Sayer // Environment and Planning

D - Society \& Space. - 1989. - Vol. 7. - No. 3. - Pp. 253-276, doi:10.1068/d070253.

38. Schmitt-EgnerP.TheConceptof'Region': TheoreticalandMethodologicalNotesonItsReconstruction/P. SchmittEgner // Journal of European Integration. - 2002. - Vol. 24, - No. 3. - Pp. 179-200, doi:10.1080/07036330270152196.

39. Shevel O. The Parliamentary Elections in Ukraine, October 2014 / O. Shevel // Electoral Studies. - 2014. - Vol.

39. - No. October 2014. - Pp. 159-163. doi:10.1016/j.electstud.2015.03.015.

40. Stölting E. New Regional Identities and Strategic Essentialism / E. Stölting et al. 2005.

41. Von Löwis S. Phantom Borders in the Political Geography of East Central Europe: An Introduction / S. Von Löwis // Erdkunde. - 2015. - Vol. 69. - No. 2 - Pp. 99-106, doi:10.3112/erdkunde.2015.02.01.

Annex A. Intraregional variability of voting patterns in Zakarpattya oblast on parliamentary elections of 2002, 2007, 2012, 2014

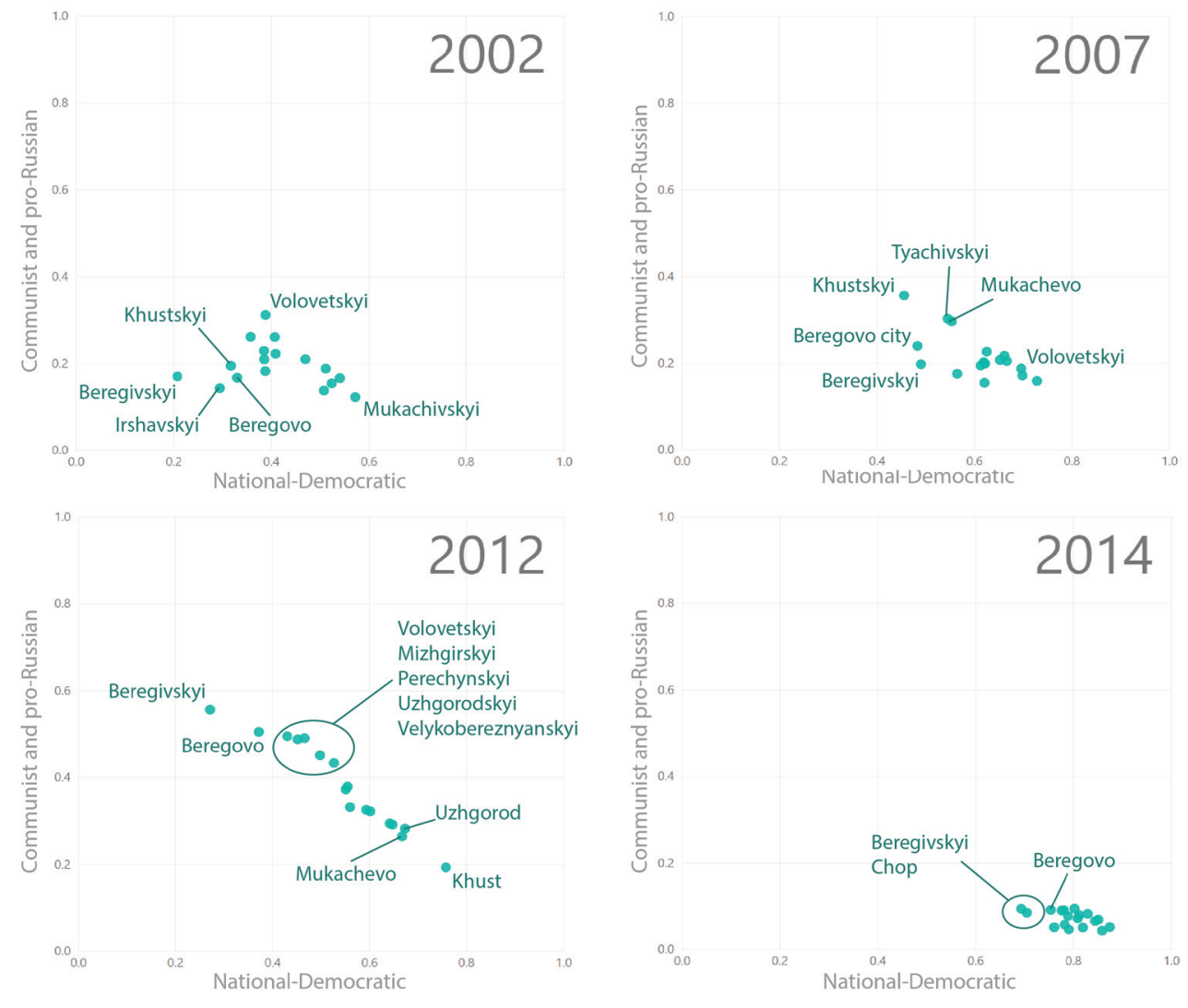


Annex B. Intraregional variability of voting patterns in Zhytomyr oblast on parliamentary elections of 2002, 2007, 2012, 2014

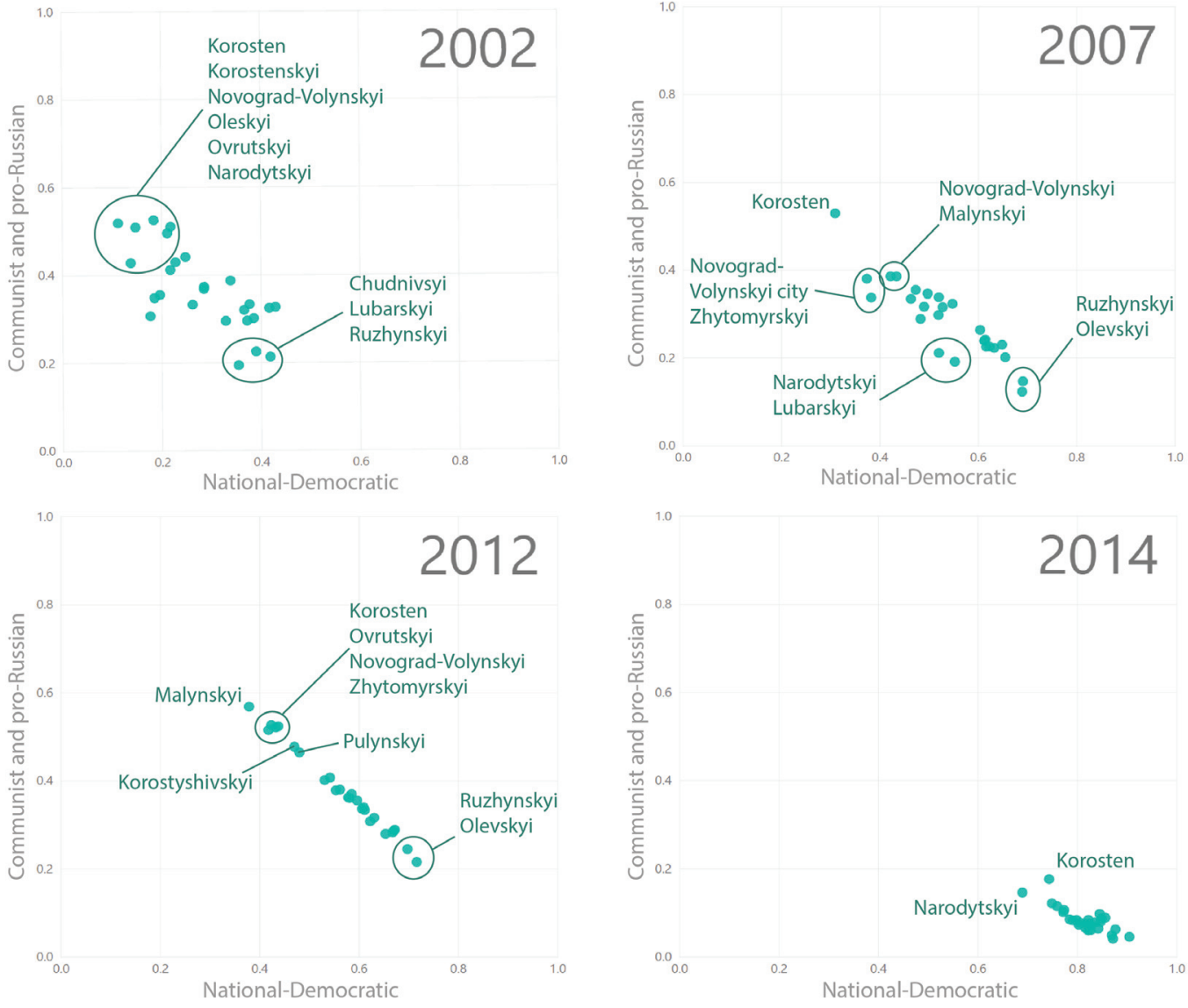

Annex C. Intraregional variability of voting patterns in Chernivtsi oblast on parliamentary elections of 2002, 2007, 2012, 2014

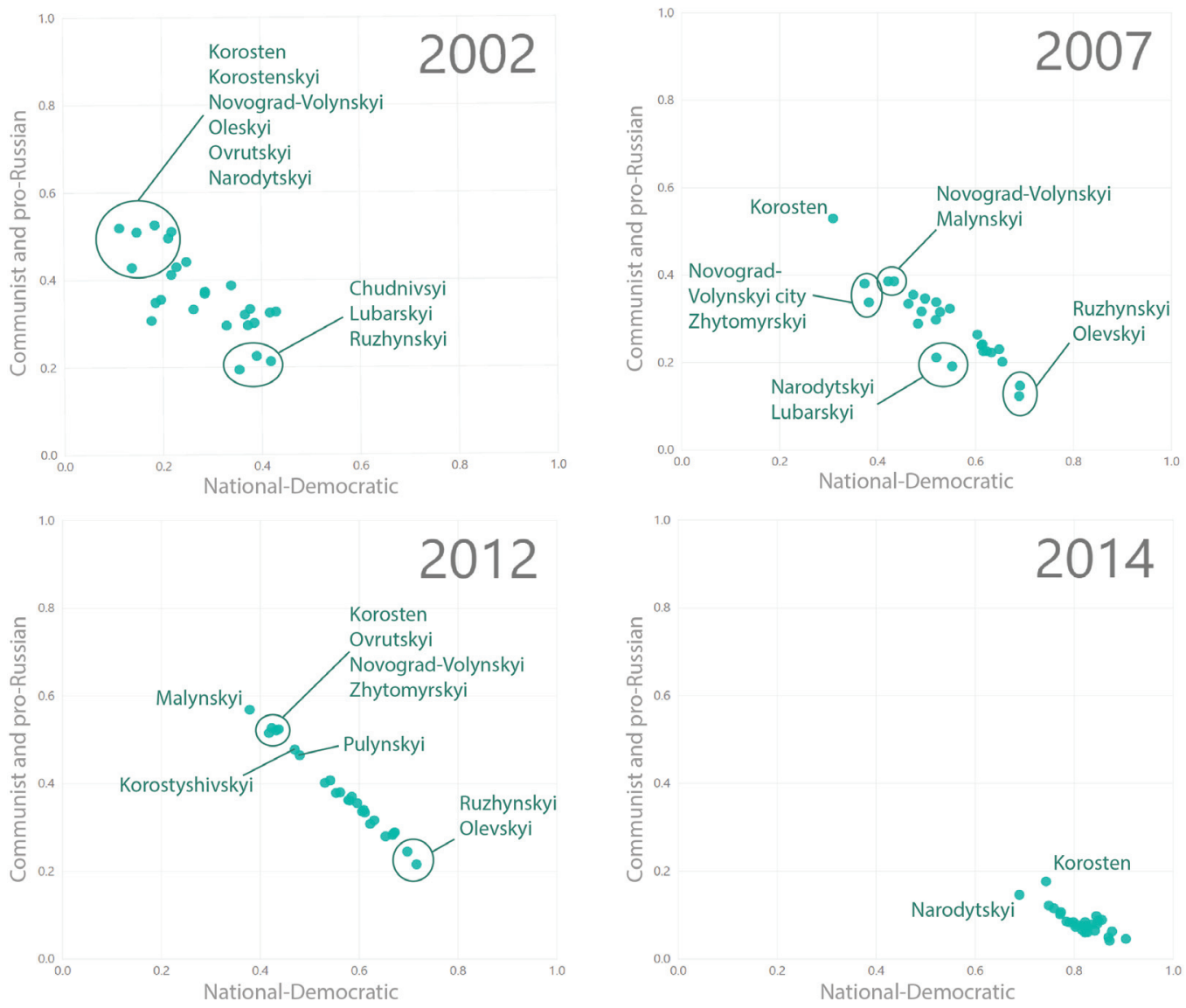

